\title{
A Study on English Language Economics of Electronic Commerce
}

\author{
Ming-Yun $\mathrm{CHI}$ \\ 191 Binhai road, Yantai, China \\ Chimingyun@126.com
}

Key words: English language economics electronic commerce

\begin{abstract}
Based on the analysis of the theory of linguistic economics, this paper puts forward the principles of linguistic Economics. The paper points out that electronic business English is closely related to economic globalization and electronics, and embodies the principle of saving energy, and the principle of convergence, the use of economic value. The purpose of this study is to explore the characteristics of the increasingly popular e-commerce English from the perspective of language economics, and value for practitioners to provide some theoretical reference.
\end{abstract}

\section{Introduction}

The evolution of world economic integration and trade globalization. The development of information technology, especially Internet technology. Changes in the pattern of cross-border e-commerce transactions. Cross Border e-commerce refers belong to different customs territory of the transaction object, the application of e-commerce platform in the process of transaction, to achieve payment settlement. Cross border logistics with the help of the delivery of goods, the realization of an international transaction. Commercial activities. Due to the rapid development of cross-border e-commerce, English has been widely used in the sphere, and has been used for special purpose. A new branch of English "e-commerce English". The emergence and development of English is undoubtedly related to the internationalization of economy and Internet technology. The wider application of technology is inseparable from the economic and Technological Development

\section{Research and Application of Language Economics}

As a new discipline in the economics of language first appeared in 1960s. American Informatics. Founder Jacob Marschak1965 in Behavioral Science for the first time in the journal Language Economics, according to his argument, language and other resources should be the same.

It has economic characteristics, which include value, utility, cost and income. Therefore, he believes that the study of economics and the optimization of language. The four aspects are studied and the existing problems are found. The main content of language economics. Twentieth Century 70,80 the influx of immigrants in North America in the 1980s, the local government departments in order to allow immigrants. More quickly integrate into the mainstream society, into the labor market, put a lot of money for language training. This makes many scholars begin to study language education. The relationship between input and output. Canada and the United States, the two largest immigrants. As the representative of the country, began to focus on the study of language economics. To become the bilingual policy of the country, the mastery and income of the language. On the reality of the relationship between the country's language planning. Such steering is determined by the background of the times.

By 90s, under the influence of North American studies, some European scholars have joined in the study of the relationship between language and economy. The most prominent representative of the Swiss University of Geneva economy professor Francois Grin. He was at the time of North America and Europe a review of the study of language economics. The scope of this period is more to explore the change and spread of language; the relationship between language and income language policy formulation and implementation, and so on.

In the field of economics, more and more linguists and educators. Began interdisciplinary research. It can be said that 1960s is the language. The beginning of the study of economics began 
in 70 s and gradually formed in $80 \mathrm{~s}, 90 \mathrm{~s}$ in a wider range of development. Twenty-first Century foreign language. The study of economics should focus on language as human capital and language economic and trade relations, immigration and related language policies linguistic analysis and gravity modeling.

\section{E-Commerce English Language Economics Analysis}

As a new form of cross-border e-commerce, in recent years has been rapid development, but also has immeasurable prospects for development. But the people can take this convenience shopping, but also conducive to changing employment promote economic growth. E-commerce English role a very important role, with the role of communication bridge, while the performance of the characteristics of the times, especially with the development of Internet technology performance abroad. International Economic and trade characteristics. In this paper, the research of electronic commerce health and development, language features, network effects, economic value the principles of economics.

\section{E-Commerce English is Closely Related to the Economy of the Times}

Economic development is the biggest driving force of language development. Sufficient conditions for expansion and propagation. As a new commercial activity. Electronic commerce, which plays a very important role in business activities, showing the way ahead is the necessary step in the development of business history section.

According to China's Ministry of Commerce announced the global trade pattern report in 2013, China's import and export value of more than 4 trillion yuan, of which 3 trillion yuan belong to cross-border electricity supplier import and export transactions, than to go the same period last year, an increase of $31 \%$; the Ministry of Commerce predicted that China in 2016. Cross border electricity supplier import and export volume will exceed 7 trillion yuan, an average annual growth speed will exceed $30 \%$. By studying the data, we can find that the traditional trade average annual growth rate of $10 \%$ or less, while cross-border E-commerce has reached more than $30 \%$, which will create new foreign trade import and export growth point.

\section{E-Commerce English Embodies the Principle of Effort}

The principle of saving effort is also called economic principle Guillaume Ferrero (1894) discovered. About 50 years later. In 1949 American linguist George Kingsley Zipf published a special with Human Behavior the of and Least Ef- Principle Fort, which has had a widespread impact. He believes that the use of language exists a tendency to achieve efficient communication with minimal effort. This principle also known as the Zipf rule. Based on his knowledge, we apply language should feel the force from different directions, that is, a single

The forces of change and the power of diversification, which play a role, but also conducive to understanding, try to use a corresponding word to represent each concept, help the listener in the shortest time. In understanding the meaning of. The word formation features of e-commerce are also able to save province, is embodied in the principle of effort.

\section{Electronic Business English Reflects the Network Effect and Trend of Language Same Principle}

Network effect is also called network externality or demand side economies of scale, the number of people buying this product increases. The value of this product will continue to rise language and products are similar network effect. 1991, nobel prize in economics Winner Reinhard and economist Jonathan Pool the game balance of foreign language skill distribution is published

There is also a network effect in language: if a language gets more people, so for others, if the conditions are not the same, then this languages will become more practical. The characteristics of language and public different product. There is no doubt that network effects are better reflected in 
language. The development of speech. The network effect can be explained by the network effect of language. The problems and development of general language in economic conditions.

\section{The Use of Electronic Business English Reflects The Economic Value.}

Language is a kind of human capital, and it needs a lot of economy. Foreign language acquisition is even more so. Through education and learning, it takes a lot of energy to master a foreign language at work. In order to acquire more knowledge and skills. People are willing to invest. It is the mastery of a foreign language that has economic value. Economic value of language. There are high and low points. Determine the level of economic value of its fundamental. It is determined by market supply and demand, in line with the general economic law. Specifically, a particular language in all departments, enterprises, professional as well as the use of various tasks. The higher the degree of use. The higher the value, and vice versa.

Cross border e-commerce activities with the Internet as the media. The commercial pattern of the system breaks through the limitation of time and space. Any enterprise or individual can at any time with any of the world. Customer communication and negotiation. Its development has caused the society. A variety of changes, including the common language used as a communication tool. Language has changed, and gradually formed a kind of e-commerce channel

English for special purposes. The emergence, development and transmission of electronic business English.

It embodies the economic attribute of language and follows the principle of Economics. The development of language form. On the theory of language economics. It helps to deepen people's understanding of E-commerce English. To reveal the economic nature of language and to better understand the economic development. The promotion of language development and communication.

\section{Reference:}

[1] Wang Lifei. An analysis of the current situation of Foreign Language Economics The study of linguistics two [J]. Shandong foreign language teaching, 2015, (3)

[2] Xu Qicha. Language Economics: a new frontier subject [J]. Foreign language, 2014, (4): 43-48

[3] Fan Yong. The lexical features and translation of electronic business English [J]. Chinese science and technology translation, 2015, (3): 36-38. 